Paper prepared for the 19th Annual European Association of Law and Economics Conference,

19-21 September 2002, Athens

\title{
RATIONALITY, ETHNICITY AND INSTITUTIONS: A SURVEY OF ISSUES AND RESULTS
}

\author{
Andreas P. Kyriacou \\ Universitat Autónoma de Barcelona \\ Departament d'Economia Aplicada \\ Edifici B \\ 08193 Bellaterra (Barcelona) \\ Spain. \\ E-Mail: Andreas.Kyriacou@uab.es
}

\begin{abstract}
This paper focuses on the relationship between institutions and ethnocentrism as discussed in the rational choice literature. The institutional environment can influence both the formation and the expression of ethnic tastes by rational individuals. Ethnocentrism is likely to be mitigated by, on the one hand, a private sector characterized by a wide and competitive market with effective property right and antitrust law enforcement provided by non-ethnic institutions and, on the other hand, a public sector which is characterized by institutional restrictions on the differential fiscal or regulatory treatment on the basis of ethnicity, a redistributive system based on non-ethnic criteria and finally, the possibility for decentralized collective decision making. These ideas may be of particular utility when designing the institutions of potentially divided multi-ethnic states.
\end{abstract}

Keywords : ethnocentrism; rational choice; institutions. 


\section{Introduction}

The abundance of literature dedicated to the study of ethnocentrism or ethnic nationalism, contrasts with the relative scarcity of studies which approach this phenomenon from the rational choice perspective. Those rational choice studies which do attempt to address this imbalance are themselves "a long way from a tolerably complete, consistent, and empirically relevant theory of nationality based on the axioms of the rational choice paradigm" (Breton et al, 1995). Further, the inability of these studies to agree on what nationalism is, and the lack of effort to explain observations on nationalism by way of differences in observable constraints, constitute two important weaknesses (Allen, 1997).

The purpose of this paper is to take a step in addressing these shortcomings by focusing on the relationship between institutions or constraints and ethnocentrism as discussed in the rational choice literature. In many of these studies rational individuals are assumed to have a taste for ethnicity their expression of which being influenced by the costs of doing so as these emerge from the institutional setting - be this within the private market sphere or the public political sphere ${ }^{1}$. The institutional environment is also seen to influence the formation of ethnic tastes over time. The approach generates a number of insights concerning the type of institutional features which could be adopted in an effort to mitigate ethnocentric behavior by individuals and as such it is particularly relevant for potentially divided multi-ethnic states.

The paper is structured as follows. In section 2 we present some of the basic elements of the rational choice approach. Section 3 is devoted to a discussion of the extent to which the institutional environment can influence the formation of ethnic tastes over time while section 4 compares the cost of ethnocentric behavior when engaged in market and collective choice and discusses the role of political entrepreneurs who may have an interest in mobilizing their ethnic group. I conclude in section 5 by discussing some of the institutional implications suggested.

\section{Individual Rationality and the Institutional Focus}

The rational choice approach to ethnic and race relations is methodologically individualistic in that it analyzes both private and collective action from the point of view of the rational individual faced with different choices (Hechter, 1986). Individuals are rational in that they are capable of choosing among alternatives arrayed in accordance with some scalar of preferedness, in a sufficiently orderly manner (Buchanan, 1990). While the ranking of alternatives need not correspond with any array of the choice alternatives that may be objectively measurable by some outside observer, the test for individual rationality requires that alternatives be classified as "goods" and "bads" and that the individual choose more rather than fewer goods, and less rather than more bads - in other words that individuals maximize their utility. In this context, a taste for ethnicity is simply defined as a positively valued consumption good which enters a rational individual's utility function - it is not defined as primordial, atavistic or generally irrational.

This rationality assumption overcomes the tautology that "people do those things they want to do" (Lee, 1988). It implies that people will behave differently in different settings because the relative costs of alternative choices change. In other words, the specification of the arguments which enter individual utility functions as positively valued goods, allows for some positive predictions concerning the effects of shifts in constraints on choice behavior, and in particular the expectation that more of a good will be chosen as its relative cost falls (Brennan and Buchanan, 1981). Generally speaking, institutions are important since like basic physical constraints or endowments, institutional structures constrain the feasible outcomes (Brennan and Buchanan, 1985, Frey 1990). Similarly, and in the context of this paper, the institutional focus stems from the insight that the expression by rational individuals of an ideological preference may be influenced 
by the costs of such expression, as these emerge from formal institutional structures, such as rules, laws and constitutions. As North (1990) states,

"where the price to individuals of being able to express their own values and interests is low, they will loom large in the choices made; but where the price one pays for expressing one's own ideology, or norm, or preferences is extremely high, they will account much less for human behavior" (p.22) ... "If the demand function is negatively sloped ... and formal institutions make it possible for individuals to express preferences at little cost to themselves, then indeed the subjective preferences that people hold play a big part in determining choices." (p.43) ${ }^{2}$.

Moreover, for purely methodological reasons if one is to analyze the effect of different formal institutional structures on the expression of a preference for ethnicity, one must logically keep preferences for ethnicity constant - at least in the shorter term - while varying the institutional setting. This allows the imputation of individual behavior to differing institutional structures and as such, subjects these to analysis. Notwithstanding this methodological approach, one must allow for the possibility that the formal institutional environment can influence the formation and change of preferences in the longer run - a possibility discussed in the following section.

\section{Formal Institutions and the Formation of Ethnic Preferences}

The incidence of formal institutions on the formation of individual preferences in general and ethnic preferences in particular has received little attention from scholars. The little that has been written points to the danger of adopting institutions which make economic self-interest coincident with ethnic identification, the importance of well defined and enforced property rights and finally, the effect of perceptions of fairness of the "system" on ethnic preference formation.

\subsection{The Institutionalized Coincidence of Economic Self-interest and Ethnic Identification}

Insofar as self-interest is not coincident with the observance of universal norms, they may be weaker than norms of exclusion and difference (Hardin, 1995b). Brennan and Hamlin (1995) argue that in the long run virtue as a disposition may flourish within an institution to the extent that it reduces the costs - in terms of other things foregone - of such behavior or, in other words, that virtuous behavior may flourish within institutions which point virtuous and self-interested behavior in the same direction. Conversely, to the extent that institutional structures make self-interest coincident with one's identification with an ethnic group, they may reinforce ethnic preferences over time.

The institutionalized coincidence of ethnic identity and self-interest was undertaken in both the Soviet Union and ex-Yugoslavia basically by making ethnic identity the basis for political entitlement. Organizational features of the Soviet Union included a federation of ethno-territorial units governed by indigenous political elites where an internal passport system fixed each citizen's ethnic affiliation. The system made rents available to ethnic leaders for distribution to their "constituents", provided that in return the leadership would channel their ethnic resources into loyal party service (Zaslavsky, 1992).

The system institutionalized "structural redistribution" from relatively wealthy nationalities to poorer ones, as a way of solving the nationalist question. This "made nationality and ethnic awareness an all-important basis for individual advancement and political competition for resources and incomes, thereby sowing the seeds of revival of aggressive nationalism when the Soviet Union began to collapse." (Ferrero, 1995; p. 227; see also, Findlay, 1995). Arguably, the institutionalization in these countries of a system which associated ethnic identity with economic 
self-interest for both citizens and political elites, set the institutional foundations for the consolidation of ethnic preferences across individuals.

This point also applies to those consociation or power sharing agreements which have been employed as a method of managing ethnic-conflict. In particular, I am referring to "proportionality rules" which require that each ethnic community be proportionally represented in the legislature, the executive, the judiciary, the civil service, and the police. This applies to both public employment and public expenditure. Proportionality may even apply to private sector employment, by requiring employers to hire a certain percentage of workers from each community. In tune with my discussion here, these arrangements have been criticized on the grounds that they entrench ethnic divisions (O’Leary and McGarry, 1995).

\subsection{The Costly Enforceability of Property Rights}

A further institution-based rational for the formation of ethnic preferences stems from the abandonment of the neoclassical assumption of costlessly enforceable property rights (Wintrobe, 1995). The existence of transaction costs in family, market or political relations, creates a demand for trust and loyalty which can be met by investment in ethnic networks and ethnic capital in general. Language, religion, mores and customs are likely to affect individuals' costs of transactions with one another (Hardin, 1995a). In particular, common traits may act as a screening device allowing individuals to predict the contractual behavior of trading partners whereas traditional codes of conduct or informal rules may act as substitutes to contract law (Landa, 1981). Moreover, the value of ethnic services in general and ethnic sanctions which facilitate exchange in particular, rises when a (central) state's enforcement activities become increasingly ineffective (Pejovich, 1993; Congleton, 1995). The possibility must also be admitted that ethnic groups may be more efficient providers of enforcement activities (Roback, 1991).

Wintrobe (1995) has discussed in some detail how the costly enforceability of property rights within families, may lead to the formation of ethnic preferences. Poor parents may make ethnic investments in their children, in return for direct support (economic or other) since they are less able to "buy" this support through bequests. The idea is that selfish parents make ethnic investments in their children in exchange for their obedience in later life in the form of direct support and attention of parents in their old age, as well as indirect support by making decisions based on their parents utility function. From the children's point of view, their parents may have over-invested in ethnic capital, especially if their accumulated ethnic capital makes it difficult for them to forge relationships with "outsiders". If moreover ethnic investments by parents are low yielding for children this leads the latter to blame other high-yielding ethnic networks and thus generate inter-ethnic hostility.

\subsection{Perceptions of Fairness}

North (1981) argues that the perceived fairness of a "system" is an inherent part of everyone's ideology and advances four developments which may change an individual's perceptions of the fairness of a "system" and thus ultimately his or her ideological conviction: an alteration in property rights which denies individuals access to resources which they had come to accept as customary or just; a decline in the terms of exchange in a factor or product market away from what had come to be regarded as a just exchange ratio; a decline in the relative income position of a particular group in the labor force; and a reduction in information costs that results in individuals perceiving that different and more favorable terms of exchange may prevail elsewhere ${ }^{3}$.

While these are framed in terms of ideology they are clearly applicable to my discussion here. Thus, for example, the denial of members of an ethnic group of access to their "ancestral 
lands" in the aftermath of inter-ethnic conflict may generate a feeling of injustice on the part of the displaced populations which over time contributes to the intensification of their ethnic tastes and leads to calls for historic retribution. Terms of exchange in a product or factor market which are perceived as unfair by one particular ethnic group or a worsening in the relative income position of a group are likely to contribute to making ethnicity a salient issue. Finally, one would expect ethnicity to become salient as an ethnic group which becomes gradually aware of receiving a "raw deal" within a bi or multi-ethnic setting ${ }^{4}$

\section{Formal Institutions and the Expression of Ethnic Preferences}

That individuals choose to express their ethnic preferences partly depends on the cost of doing so as this emerges from the institutional setting. In particular I will compare the rationality of ethnic expression in the atomistic institutions of the market with that in the context of institutions for collective or public choice. Unlike market choice, collective choice tends to be both indecisive and secret and as a result the cost of ethnic expression relatively lower. In either context, rents exist for political entrepreneurs who can organize ethnocentric behavior across their group and as a result one would expect politicians to strive to appropriate these rents.

\subsection{The Cost of Ethnic Expression in the Atomistic Institutions of the Market}

What would be the cost faced by an individual in the market place, of expressing a preference for ethnicity? An individual with a taste for discrimination would be willing to pay to avoid contact with members of another ethnic group (Becker, 1957). In the context of two ethnic groups A and B, an employer from group A may be willing to pay higher wages to avoid hiring workers from group $\mathrm{B}$; a worker from A may be willing to accept lower wages to avoid working with workers from B; a consumer from A may be willing to pay higher prices to avoid buying goods produced by individuals in B. The premium paid is the result of the self-imposed artificial scarcity which emerges when limiting one's range of choice to fellow ethnics. It will vary with the economic cycle (Leiman, 1993). For example, in an increasingly tight labor market, employers who restrict their hiring to their "preferred" ethnic group, would find it increasingly costly to do so. On the other hand, employees is such a market may find it cheaper to indulge discriminatory preferences, given rising wages and the receding risk of prolonged unemployment.

The premium represents the immediate cost of expressing one's ethnic tastes in the market. A subsequent cost facing an individual whose ethnic tastes limit his/her range of choice is, of course, that the individual may be priced out of the market (Becker, 1957; Friedman, 1962). This depends on the degree of competition in the market which in turn depends on the degree of dispersion of ethnic tastes and the degree of substitutability of individuals in their various private economic roles, as employers (in terms of entrepreneurialness and access to capital), employees (in terms of productivity) and consumers (in terms of purchasing power). Not surprisingly, a monopolist can indulge in discrimination in the longer-run since first, it has uniform tastes by definition and second, it enjoys above-competitive profits and as such can sacrifice a part of these to indulge in discriminatory preferences (Cain, 1986).

In short, the competitive market can oblige an individual with a preference for ethnicity to pay a premium which approaches the full value of expressing this preference (and the full value, at the theoretical limit of perfect competition) or stated differently, that the competitive market potentially represents an institutional framework which is incentive incompatible with ethnocentric behavior. 


\subsection{The Cost of Ethnic Expression in the context of Institutions for Collective Choice}

Ethnicity has been defined as a private consumption good that yields satisfactions to those individuals who are willing to pay for it. This private good nature of ethnicity can be carried over into collective choice by arguing that people engaged in such choice may gain an "intrinsic consumption benefit from casting a vote in a particular way" (Brennan and Buchanan, 1984). This said, what would be the cost of ethnic expression in the context of institutions for collective choice? The answer is likely to depend on several factors including, the likelihood of one's vote being decisive and whether or not one's vote is secret. In general one could suggest that while the individual may pay the full price of choosing to consume an intrinsic consumption benefit in the market, this may not be the case in the polity given the fact that unlike market choice, collective choice can be both indecisive and secret.

The likelihood that one's vote does not decide the electoral outcome leads the individual to discount the expected instrumental cost of his/her choice and to vote "expressively" (Brennan and Lomasky (1993). The probability of being decisive depends on both the size of the collective choice unit and the voting rules in place. In particular, the greater the group and the less inclusive the voting rules, the less likely that one's vote will be decisive. The indecisiveness argument has been linked by the previous authors to various historical phenomena including the rise to power by Hitler in pre-W.W.II Germany, the consigning of Jews to concentration camps, the emergence of legislation barring blacks from certain occupations and the declaration of war. Similarly, North (1990) argues that the electoral process made it possible for Northerners to express their abhorrence of slavery in the U.S at relatively little cost to themselves but at a high cost for slave owners. Roback (1986) explains streetcar segregation in the US South of the 1890's in these terms. The relative importance of expressive elements when voting for ones political representatives points to the likelihood that political entrepreneurs facing electoral competition will tend to tailor their campaigns to cater for these expressive considerations (Brennan and Hamlin, 2000). In particular they may employ rhetoric which emphasizes existing ethnic boundaries or invents new ones.

A second rational why people may be more likely to express their ethnic tastes when engaged in collective decision-making stems from Kuran (1993) who argues that voters may have true private preferences and false public preferences which beyond their personal tastes reflect the anticipated reactions of others. In terms of my discussion here, if a preference for ethnicity has a bad ethical reputation socially, individuals may falsify their private (ethnic) preferences, at a psychological cost to themselves in the form of foregone intrinsic consumption benefits. However, while individuals may be led to falsify their true private preferences in the market, they need not do so when deciding collectively assuming decisions there are taken by secret ballot. In this case and compared to market choice, collective choice provides an institutional framework which facilitates the expression of ethnic tastes when such expression flows against public morality. Of course, the possibility also exists of ethnic behavior being held at high esteem socially while privately it may be eschewed.

Kuran (1993) goes on to argue that to the extent that social pressures breed preference falsification this eventually leads to the "tyranny of public opinion" and cynicism something which creates opportunities for extremist politicians who represent an extreme version of the private preferences. At election time, individuals are presented with an opportunity to freely express their private ethnic preferences in the voting booth and the real possibility emerges that these preferences coincide with the discriminatory electoral programs of extremist political entrepreneurs. This may lead to an "unanticipated revolution", as the corresponding burst of nationalism appears all the more sudden because information about true private preferences was previously hidden (Lafay, 1995).

This is all the more likely when voters are uncertain as to candidates future positions and elections coincide with crisis periods. Enelow and Hinich's (1981) have argued that because of 
high information requirements and deliberate attempts by centrist candidates not to define themselves, voters may be uncertain as to candidates' future positions. Conversely, the position of extreme candidates is a much clearer predictor of future actions. Lafay (1995) points out that this strong pre-commitment to settled positions by extremist groups, wins them electoral support during crisis periods since it decreases voter uncertainty. The opposite happens in non-crisis period where the lower destabilizing capacity of centrist parties is preferred by voters.

\subsection{Psychic and Instrumental benefits from Ethnic Group Mobilization}

So far in the discussion, the individual is assumed to gain utility from his/her own expression of ethnic tastes in the form of an intrinsic consumption benefit. But the possibility must also be admitted that choosing individuals may gain utility from the parallel expression of ethnic preferences by others or in other words, from the mobilization of their ethnic group. In the spirit of Sen's (1970) meddlesome preferences, individuals may simply obtain psychic satisfaction from the knowledge that others also conform to an ethnic norm governing social relations (Roback, 1989). Individuals may moreover receive psychic utility from ethnocentric behavior by others in society since this gives them a context in which to enjoy their own preferences for things ethnic, including language and culture. More menacingly, individuals may have an interest in the expression of ethnic tastes by their fellows since this may yield the psychological benefits of power and prestige (Pagano, 1995) ${ }^{5}$.

There may also be an instrumental component to the utility gain from the generalized expression of ethnic preferences when engaged in both market and public interaction. Gains in the former context includes, social insurance (Congleton, 1995), job referral, reduced transaction (Wintrobe, 1995) and enforcement costs (Landa, 1981; Roback, 1991). Gains from the mobilization of one's ethnic group in the polity could take several forms. First, policies which reflect one's ethnic tastes for public goods. Thus, by voting as a block an ethnic group may decide the provision of public goods which are consistent with its ethnic preferences or conversely it may avoid having to having to consume public goods which may not represent one's ethnic preferences. This is more likely when political decisions are taken over non-tradable issues such as nationality, language, territorial homelands, and culture (O'Leary and McGarry, 1995). Second, policies which reduce competition from other ethnic groups in the market. Economic rents emerge from the exclusion of individuals of other races from competing economic activities (Krueger, 1964). Third, policies that institute the direct inter-ethnic redistribution of resources from other ethnic groups either in the form of transfers or assets including land, buildings and infrastructure, government machinery and bureaucracies (Breton, 1964; Johnson, 1967; Coleman, 1995; Hardin, 1995a; Breton and Breton, $1995)^{6}$. Again, the general expression of ethnicity when engaged in public choice may avoid the loss of such rents due to the mobilization of other ethnic groups. In sum, an individual may vote ethnically therefore in an effort to avoid the costs of finding him or herself in a dissenting minority ${ }^{7}$.

The general conformity with an ethnic norm governing social relations is a public good which would be underprovided as people free-ride on others' conformity and this under-provision is inefficient in a positive predictive sense rather than a normative prescriptive one (Roback, 1989). Indeed, it is arguably efficient in this latter sense and in this respect consider Hardin (1995b) who states that,

"Adam Smith's argument for why the untrammeled market is likely to be better than a system in which various groups gain political control over production, distribution, or whatever was essentially an argument that successful collective action about such matters would typically be harmful. The happy fact that collective action is hard to motivate if it is 
not organized by government was the back of Smith's invisible hand that lead individuals to prosper. The back of that hand blocks groups from wrecking individual prospects." (p. 5)

The free rider problem may be overcome in small communities (e.g., rural ones) which may allow for the supervision and sanctioning of individual members who do not conform to the racist norm in the market (Akelrof, 1985). Individuals may be mobilized in both small and large groups with the aim of changing a status quo situation which is perceived to be unfair (North, 1981, Banton, 1983). The tendency to free ride may be weaker among individuals who form part of a committed self-sacrificing disciplined minority of the group (Olson, 1965/1971).

\subsection{Rents for Political Entrepreneurs}

Notwithstanding the just mentioned cases, the possible psychic and instrumental benefits from the generalized expression of ethnic tastes means that political rents emerge for those who are able to coordinate such conformity. While the political mobilization of an ethnic group may be costly for all groups and is in a sense therefore irrational from that perspective (a negative sum game), it may be rational from the perspective of political entrepreneurs who strive to appropriate electoral rents and who expect to share the costs with others (De Jasay, 1998) ${ }^{8}$.

Given the previous discussion, one would expect political entrepreneurs not to limit themselves to expressive considerations during elections but also to make allusion to the likely instrumental benefits from casting one's vote ethnocentrically or the instrumental costs of not doing so. In the particular case of political entrepreneurs standing on secessionist platforms they may focus on the instrumental benefits and play down the expected costs of independence (the opposite would be expected from political entrepreneurs trying to avoid the breakdown of the multi ethnic state). For example, secessionists leaders may make references to the more efficient provision of government services within the context of the "new" state, as well guarantee the continued economic association of this state with the "old" one and the likely economic association of their ethnic group within a larger trading network such as a regional or international trade regime. In the case where their group is a net contributor to the finances of the "old" state they would be expected to associated independence with reduced tax burdens. Alternatively, if the group is a net recipient, one would expect them to remain silent on any losses of transfers from the central government of the "old" state".

In addition, politicians can go about mobilizing their ethnic group by way of selective incentives of the usual negative and positive variety. Selective incentives may take the form of legal penalties (fines, incarceration), social sanctions (ostracism), social rewards (status and respect) and economic prizes (transfers or assets) ${ }^{10}$. Moreover, political entrepreneurs may resort to propaganda in an effort to influence the perceived benefit or cost of free riding in larger groups. For example, propaganda may be aimed at making free riders experience dissonance (guilt) either because they reduce the psychic and economic utility obtained by others or because they 'betray' the ethnic group's historical legacy. Propaganda may help mobilize ethnic groups to the extent that it can convince people that the status quo situation is unjust. Propaganda is likely to be especially important in the context of political choice given the inability to identify and punish free riding in the voting booth.

The level of effort that political entrepreneurs put into the coordination of selective incentives is a function of several factors. First, the degree of competitiveness of ethnic elites vis-à vis those of other ethnic groups and vis-à-vis up-and-coming elites from the same ethnic group (Johnson, 1967; Breton and Breton, 1995). The idea is that in a competitive environment, the members of an ethnic group or collectivity can evaluate the performance of their own elites by reference to the conduct of other elites. If ethnic elites are not "competitive" they may eliminate or reduce competition by cultivating nationalism and in particular engaging in xenophobic 
propaganda, effectively a protectionist measure Similarly, Hardin (1995b) argues that ethnic hostilities are a successful device for abstracting the populace from seeing the extensiveness of government failure. Politicians may seek to increase their degrees of freedom by resorting to a "top down" legitimization of their acts, that is by arguing that beyond being accountable to the interests of their fellow group members, they are accountable to history itself (Wintrobe, 1995).

Second, Johnson (1967) agues that where opportunities in the market sector are relatively scarce - something which is especially the case in developing countries - the costs to politicians who lose elections are high and they may then have a greater incentive to resort to a preclusive (discriminatory) ideology so as to enjoy exclusive control of government. A variant of this argument refers the potential destruction of the "productivity of hordes of bureaucrats" due to a state's transition from a command to a market economy (the case of the ex-Yugoslavia and the former-Soviet Union) as an explanation of the rise of "bureaucratic nationalism" (Hardin, 1995b).

The effectiveness of positive selective incentives, will likely depend on the responsiveness of individuals. Ethnic group members may be more likely to be attracted by social rewards or economic prizes the lower the yield of their ethnic capital in the market (I am referring here to the instrumental benefits from the general conformity with an ethnic norm in the market), especially since the very high cost of entry into and exit from an ethnic group means that yields are unlikely to be equalized by market forces (Wintrobe, 1995).

Moreover, economic benefits may be increasingly valued the more limited the income opportunities in the private sector (Hardin, 1995a; Congleton, 1995) and the lower one's income (assuming such benefits are inferior goods, see Lafay, 1995). Insofar as both private sector opportunities and incomes are lower during downturns in the economic cycle then one would expect politicians to be more successful in politicizing ethnicity during these times and less so during upswings in the cycle. This idea is reinforced by the previous insight that extremists politicians strong pre-commitment to settled positions wins them electoral support during crisis periods since it decreases voter uncertainty ${ }^{11}$.

\section{Summary and Institutional Implications}

The political mobilization of ethnic groups may lead to the typical deadweight losses which result from rent-seeking activities which make societies poorer or the may threaten the very viability of the state with potentially catastrophic consequences (Congleton, 1995). I close this paper by summarizing the main findings and drawing out those institutional implications suggested by the previous discussion.

\subsection{Institutions and Ethnic Preference Formation}

Ethnic tastes may be weakened over time if the institutional framework does not make it in one's economic interest to identify with his/her ethnic group. One institutional environment which divorces the positive relationship between ethnocentrism and economic return is of course the competitive market. Pejovich (1993) has argued that capitalist institutions may eliminate nationalism in Eastern Europe since, "Driven by their self-interest, people would, sooner or later, learn to judge others on merit and performance rather than on ethnic origin" (p. 73), the implication being that if they don't they will pay the price in terms of reduced competitiveness. Banton (1993) argues that the principal that "pecunia non olet" (money has no smell) will tend to soften group boundaries. In the context of the U.S. South, he states that "If every man has a price, the price mechanism and the notion of 'good business' pose the greatest of threats to a social system such as that of the Deep South. The most effective defense is to arrange the society so that, as far as possible, people whose price might be low are never put in the position in which they can discover 
just what their price is." (p.134). More generally, Hirschman $(1977 ; 1982)$ has argued that the individual's pursuit of economic self-interest through commerce and industry would generate as a desirable by-product or external economy, the taming of one's passions by his interests (what this authors labels, the doux-commerce thesis) ${ }^{12}$.

Insofar as political institutions are concerned, again they should arguably avoid linking ethnic identification with economic self-interest and ideally, would institutionalize the coincidence between economic self-interest and universal norms. This includes the avoidance of a system of "structural redistribution" from wealthier ethnic groups to relatively poorer ones as well as "proportionality rules" which may apportion both public employment and public expenditure and even private employment on the basis of ethnicity. Redistribution and employment should be ideally be based on, respectively, relative income and merit or achievement.

Ethnic preferences may be formed over time in response to the costly enforceability of property rights in family, market and political relations. Insofar as the latter two institutional contexts are concerned this points to the importance of adopting formal institutions which can effectively enforce property rights including, non-ethnic and effective courts as well as political institutions subject to institutional checks and balances and exposed to an impartial media in an effort to mitigate the principle agent problem. Insofar as ethnic loyalty is fomented through porkbarrel projects and political patronage directed towards one's ethnic group (Wintrobe, 1995) than this points to the need to design political institutions so that they minimize ethnic rent-seeking activities. Notwithstanding these institutional prescriptions, one would expect the influence of informal rules based on ethnicity to persist for some time while individuals become accustomed and respond to the new formal rules (North, 1981).

With regards to transactions costs in families and to the extent that ethnic preferences are shaped through parental indoctrination in poor families in return for direct support by siblings in the future, less ethnocentrism would be expected in societies with generous pension or social security (Wintrobe, 1995). In addition, to the extent that parents take their children's welfare into account, they will invest more or less ethnic capital in their children depending on the degree of competitiveness of both the market and its importance compared to the public sector. If the market sector is competitive and relatively important (relative to the polity), then those altruistic parents which invest heavily in their children's ethnic capital may limit their range of choice and ultimately price them out of the market. All other things being equal, one would therefore expect rational and altruistic parents to tone down such investments when the market is both relatively important and competitive.

Ethnicity is likely to emerge as a salient issue and ethnic groups mobilized by perceived injustices. Formal rules should, as far as possible aim to avoid institutionalizing these perceptions. In relation to this they should avoid institutionalizing the inter-ethnic distribution of resources either in the form of the uncompensated confiscation of assets (such as territory), the distribution of assets from wealthier ethnic groups to poorer ones (structural redistribution and proportionality rules) or, in the form of ethnically discriminatory treatment through budgetary and regulatory policy. To the extent that the market is perceived as providing openness if not equality of opportunity and is considered to be responsive to effort, it may encourage individual's to set aside ethnicity thus softening group boundaries (Lane, 1986).

\subsection{Ethnic Behavior in Market versus Collective Choice}

The comparative institutional analysis of the institutional costs of ethnic behavior by rational individuals with a taste for ethnicity when engaged in market and collective choice allows point to the following policy implications. First, the cost of expressing one's ethnic tastes in the market is positively related to the degree of competition therein, and so one's ability to indulge in the 
expression of ethnic tastes in the long-run is a function of one's degree of monopoly power. This points to the need for anti-trust legislation so as to limit the exercise of monopoly power and ultimately to promote the degree of competition in the market.

Second, institutions for collective choice are more likely than not to reduce the cost of expressing one's ethnic tastes in return for an intrinsic consumption value. This so because of the relative indecisiveness of one's vote and the likely secrecy of political choice. As a result one would expect to observe more ethnic behavior in public choice rather than market choice. This points to the importance of widening the sphere of market choice, or conversely narrowing that of political choice in divided societies. A case also emerges for political decentralization which, through its reduction of the size of the decision-making unit, necessarily makes voting more decisive and as such would tend to tone down the expression of ethnic tastes in the polity (Brennan and Lomasky, 1993). Finally, to the extent that the expression of ethnic tastes is held at low esteem socially, a case emerges for open voting while a secret ballot would be more suitable where social mores favor ethnic expression.

The expression of ethnic tastes in the polity is more likely because an individual engaged in public choice is much more likely to end up as a member of the dissenting minority than one engaged in market choice. This of course has important implications for the design of political structure. First, it points to the need for institutional restrictions on differential fiscal or regulatory treatment on the basis of ethnicity. Second, it suggests the importance of decentralized collective decision-making in policy areas over which tastes across the population are split across ethnic lines. Ultimately, decentralization by allowing ethnic groups to satisfy their preferences, may reduce the potential for conflict (Kimenyi, 1996) ${ }^{13}$. This said and all other things being equal, one would expect more centralization in states with effective constitutional restrictions to the discriminatory treatment of individuals on the basis of ethnicity (Congleton et al, 1998).

Rents may exist for political entrepreneurs who can coordinate the organized conformity with an ethnic norm governing ethnic relations by individuals engaged in both market and collective choice. In their efforts to mobilize their ethnic group, political entrepreneurs may resort to propaganda and this points to the importance of independence and plurality of the mass media or conversely the dangers which may emerge when it is controlled by politicians. The responsiveness of ethnic group members to these efforts is likely to depend on the attractiveness of ethnic political mobilization and this in turn is likely to depend in part on the opportunities available in the market sector and one's position in the income distribution curve.

That political entrepreneurs seek out such rents must surely be influenced by the opportunities available to them in the private sector as well as their competitiveness vis-à-vis the ethnic elites of other groups as well as up-and-coming elites from their own group. While the competitive market may limit the expression of ethnicity, the competitive polity may promote it. This presents a case for guaranteeing each ethnic group a minimum degree of political representation with the aim of reducing the incentive of political representatives to play the ethnic card to gain office. Of course, this is a feature of power sharing systems previously criticized for potentially hardening ethnic boundaries. The question that emerges is whether the electoral system can be engineered so that it can both maintain the benefits of a minimum degree of representation for ethnic groups while at the same time avoid entrenching ethnocentrism. One way of doing so is through a system of "cross-voting" whereby electors could vote not only their communal candidates but for candidates standing on non-communal tickets as well. Other systems include "vote-pooling" and "preference swapping" at the core of which is to make politicians reciprocally dependent on the votes of members of groups other than their own ${ }^{14}$. 


\section{References}

Akelrof, G.(1985). 'Discriminatory, Status-Based Wages among Tradition-Oriented, Stochastically Trading Coconut Producers', Journal of Political Economy, 1985: 265-76.

Allen, D.(1997). 'A Survey of Nationalism and Rationality ', Journal of Economic Literature, 35(2): 820821.

Arrow, K.(1973). 'The Theory of Discrimination', in Orley Ashenfelter and Rees, A. (ed.), Discrimination in Labor Markets, Princeton, Princeton University Press.

Austin, A.(1996). 'The Price of Nationalism: Evidence from the Soviet Union', Public Choice, 87: 1-18.

Banton, M.(1983). Racial and Ethnic Competition, Cambridge University Press.

Becker, G.(1957/1971). The Economics of Discrimination, Chicago: Chicago University Press.

Becker, G.(1976). The Economic Approach to Human Behavior, Chicago: Chicago University Press.

Brennan, G and Buchanan, J.(1981). 'The Normative Purpose of Economic 'Science': Rediscovery of an Eighteenth Century Method', International Review of Law and Economics, 1: 155-166.

Brennan, G and Buchanan, J.(1984). 'Voter Choice. Evaluating Political Alternatives', American Behavioral Scientist, 28(2):185-201.

Brennan, G. and Buchanan, J.(1985). The Reason of Rules. Constitutional Political Economy, Cambridge University Press.

Brennan, G and Hamlin, A.(1995). 'Economizing on Virtue', Constitutional Political Economy, 6: 35-56.

Brennan, G and Hamlin, A. (2000): 'Nationalism and Federalism: The Political Constitution of Peace', in Galleotti, G., Salmon, P. and Wintrobe, R. (eds), Competition and Structure: The Political Economy of Collective Decisions: Essays in Honor of Albert Breton, Cambridge and New York: Cambridge University Press.

Breton, A.(1964). 'The Economics of Nationalism', Journal of Political Economy, 72(4): 376-386.

Breton, A and Breton, M.(1995). 'Nationalism Revisited', in Breton, A., Galeotti, G., Salmon, P and Wintrobe, R. (eds.), Nationalism and Rationality, Cambridge University Press, 98-115.

Breton, A., Galeotti, G., Salmon, P and Wintrobe, R. (eds.).(1995). Nationalism and Rationality, Cambridge University Press.

Buchanan, J.(1954). 'Individual Choice in Voting and the Market', Journal of Political Economy, 62: 334-43.

Buchanan, J.(1979). What Should Economists Do?, Liberty Press, Indianapolis.

Cain, G.(1986).'The Economic Analysis of Labor Market Discrimination: A Survey', in Ashenfelter, O. and Layard, R. (eds.), Handbook of Labor Economics, Elsevier Science Publishers, Volume I: 693-785.

Coleman, J.(1995). 'Rights, Rationality, and Nationality', in Breton, A., Galeotti, G., Salmon, P and Wintrobe, R. (eds.), Nationalism and Rationality, Cambridge University Press, 1-13.

Congleton, R.(1995). 'Ethnic Clubs, Ethnic Conflict, and the Rise of Ethnic Nationalism', in Breton, A., Galeotti, G., Salmon, P and Wintrobe, R. (eds.), Nationalism and Rationality, Cambridge University Press, 71-97.

Congleton, R., Kyriacou, A. and Bacaria, J. (1998): Political and Economic Origins of Asymmetric Federalism, Mimeo: Universitat Autònoma de Barcelona.

De Jasay, A. (1998): 'Is National Rational', The Independent Review 8(1): 77-89.

Enelow, J. and Hinich, Melvin.(1981). 'A New Approach to Voter Uncertainty in the Downsian Spatial Model', American Journal of Political Science, 25(3): 483-493. 
Ferrero, M.(1995). 'The Economics of Socialist Nationalism: Evidence and Theory', in Breton, A., Galeotti, G., Salmon, P and Wintrobe, R. (eds.), Nationalism and Rationality, Cambridge University Press, 204- 244.

Findlay, R.(1995). 'Notes on the Political Economy of Nationalism', in Breton, A., Galeotti, G., Salmon, P and Wintrobe, R. (eds.), Nationalism and Rationality, Cambridge University Press, 143-158.

Frey, B.(1990): 'Institutions Matter', European Economic Review 34: 443-449.

Friedman, M.(1962). Capitalism and Freedom, Chicago and London: Chicago University Press.

Hardin, R.(1995a). 'Self-interest, Group Identity', in Breton, A., Galeotti, G., Salmon, P and Wintrobe, R. (eds.), Nationalism and Rationality, Cambridge University Press, 14-42.

Hardin, R.(1995b). One for All. The Logic of Group Conflict, Princeton, New Jersey: Princeton University Press.

Hechter, M. (1986). 'Rational Choice Theory and the Study of Race and Ethnic Relations', in Rex, John and Mason, David. (eds), Theories of Race and Ethnic Relations, Cambridge University Press.

Hirschman, A. (1977). The Passions and the Interests, Princeton, New Jersey: Princeton University Press.

Johnson, H.(1967). 'A Theoretical Model of Economic Nationalism in New and Developing States', in Johnson, Harry (ed.), Economic Nationalism in Old and New States, Chicago: Chicago University Press.

Khun, T.(1962). The Structure of Scientific Revolutions, University of Chicago Press.

Kimenyi, M.(1996): Ethnicity and Liberty: The African Dilemma, The Lock Institute, Edward Elgar.

Krueger, A.(1963). 'The Economics of Discrimination', Journal of Political Economy, 481-86.

Kuran, T.(1993). 'Mitigating the Tyranny of Public Opinion', Constitutional Political Economy, 4(1): 41-78.

Kyriacou, A.(2000): 'An Ethnically Based Federal and Bicameral System: The Case of Cyprus', International Review of Law and Economics 20(2):261-268.

Kyriacou, A.(2001): 'On the Viability of Potentially Divided Multi-Ethnic States', Journal of Public Finance and Public Choice 19(1): 121-135.

Lafay, J. (1995): 'Conservative Nationalism and Democratic Institutions', in Breton, A., Galeotti, G., Salmon, $\mathrm{P}$ and Wintrobe, R. (eds.), Nationalism and Rationality, Cambridge University Press, 159-172.

Landa, J. (1981): 'A Theory of the Ethnically Homogeneous Middleman Group: An Institutional Alternative to Contract Law', Journal of Legal Studies 10: 349-62.

Lane, R. (1986). 'Market Justice, Political Justice', American Political Science Review, 80(2): 383-402.

Lee, D.(1988). 'Politics, Ideology, and the Power of Public Choice', Virginia Law Review, 74: 191-198.

Leiman, M.(1993). The Political Economy of Racism. A History, London, Boulder Colorado: Pluto Press.

Lingle, C.(1991). 'The Political Economy of Apartheid', Annuari Societat Catalana d'Economia, 8.

Lowenberg, A.(1989). ‘An Economic Theory of Apartheid', Economic Inquiry, 27(1): 57-74.

Meadwell, H.(1993). 'Transitions to Independence and Ethnic Mobilization', in Booth, W., James, P and Meadwell, H. (eds.), Politics and Rationality, Cambridge University Press.

North, D.(1981). Structure and Change in Economic History, New York, London: W. W. Norton and Company.

North, D.(1986). 'The New Institutional Economics', Journal of Institutional and Theoretical Economics, 142: 230-237.

North, D.(1990). Institutions, Institutional Change and Economic Performance, North Cambridge: Cambridge University Press. 
O’Leary, B and McGarry, J.(1995). 'Regulating Nations and Ethnic Communities', in Breton, A., Galeotti, G., Salmon, P and Wintrobe, R. (eds.), Nationalism and Rationality, Cambridge University Press, 245-289.

Olson, M.(1965/1971). The Logic of Collective Action. Public Goods and the Theory of Groups, Cambridge Mass., London: Harvard University Press.

Olson, M.(1969). 'The Relationship of Economics to the other Social Sciences", in Lipset, S. (ed.), Politics and the Social Sciences, New York: Oxford University Press, pp.137-162.

Pagano, U.(1995). 'Can Economics Explain Nationalism?', in Breton, A., Galeotti, G., Salmon, P and Wintrobe, R. (eds.), Nationalism and Rationality, Cambridge University Press, 173-203.

Pejovich, S.(1993). Institutions Nationalism, and the Transition Process in Eastern Europe, Social Philosophy and Policy, 10:65-78.

Reilly, B. and Reynolds, A. (1999): 'Electoral Systems and Conflict in Divided Societies', Papers on International Conflict Resolution 2, Washington, D.C.: National Academy Press.

Roback, J.(1986). 'The Political Economy of Segregation: The Case of Segregated Streetcars', The Journal of Economic History, XLVI(4): 893-917.

Roback, J.(1989). ‘Racism as Rent Seeking', Economic Inquiry, 27: 661-681.

Roback, J.(1991). 'Plural but Equal: Group Identity and Voluntary Integration', Social Philosophy and Policy, 8(2): 60-80.

Sen, A. (1970): 'The Impossibility of a Paretian Liberal, Journal of Political Economy 78: 152-157.

Wintrobe, R.(1995). 'Some Economics of Ethnic Capital Formation and Conflict', in Breton, A., Galeotti, G., Salmon, P and Wintrobe, R. (eds.), Nationalism and Rationality, Cambridge University Press, 4370 .

Young, R. (1994): 'The Political Economy of Succession: The Case of Quebec', Constitutional Political Economy 5:221-245.

Zaslavsky, V.(1992): 'Nationalism and Democratic Transition in Postcommunist Societies', Daedalus: 97122.

\section{Notes}

\footnotetext{
${ }^{1}$ Ethnocentric behavior has also been explained without recourse to ethnic tastes by people working within the rational choice approach. For example, Krueger (1963) has explained racist behavior solely in terms of the economic interest of a relatively larger white community, the workers of which can make themselves better off by imposing a tariff on the hiring of black labor. Similarly, Lowenberg (1989) and Lingle (1991) have analyzed apartheid in South Africa as basically the outcome of economic rent-seeking by white workers and agricultural capitalists to the economic detriment of blacks. Arrow (1973) has argued that ethnic discrimination in the labor market, may occur due to risk averse employers who are imperfectly informed as to the real productivities of workers.

${ }^{2}$ The price for ethnicity, or more precisely given ethnicity is not a material good, the "shadow" price of ethnicity (Becker, 1976), is simply the opportunity cost of using scarce resources to satisfy ethnic preferences. The demand for ethnicity or ideological preferences in general can be seen to be inversely related to its price or opportunity cost, even though the elasticity of the function may be specific to the issue and the individual (North, 1986). This is not inconsistent with a notion of cost, or more generally of value, as subjective to each individual chooser (Buchanan, 1979).

${ }^{3}$ For these changes in relative prices to change a person's ideology they must be persistent changes which lead to the accumulation of inconsistencies between one's ideology and personal experience, much in the same way as Kuhn's (1962) scientific revolutions are brought about by an accumulation of anomalies between "normal science" and scientific evidence, forcing the scientist into a new paradigm (North, 1981).
} 
${ }^{4}$ For an extended discussion of the importance of the perceived justice of the "system" on the viability of vulnerable multi-ethnic states see Kyriacou, 2001.

${ }^{5}$ Power and prestige are simultaneously public goods for the members of the same group and positional goods such that the positive consumption by one group implies their negative consumption by another.

${ }^{6}$ Where political mobilization takes the form of the inter-ethnic redistribution of assets and "foreigners" are compensated for their losses by way of general taxes imposed on the working class majority then it is regressive (Breton, and Breton, 1995). This said, the possibility exists that psychic benefits accrue to individuals from having property in the hands of fellow nationals and as a result they may be compensated for the loss of material income "so that nationalistic policies arrive at a quite acceptable result from the standpoint of maximizing satisfaction" (Johnson, 1967).

${ }^{7}$ In this respect, consider that unlike political choice where the individual is confronted with mutually exclusive alternatives, in the market the individual is confronted with the law of diminishing returns meaning that in the market the individual is never placed in a position of being a member of a dissenting minority (Buchanan, 1954). Similarly, Olson (1969) has pointed out social cohesion may be expected to suffer when public goods are provided over which there are inter-personal differences in tastes and whose consumption by one individual implies by definition, their simultaneous consumption by others.

${ }^{8}$ This is not to say that political entrepreneurs have no taste for ethnicity. Like Olson's (1965) committed minority, they may in fact have more intense tastes. Whatever the case and like individuals in general they will express these tastes or, in other words, strive to mobilize their ethnic group depending partly on the costs of doing so as these emerge from the institutions in place.

${ }^{9}$ The cost of secession may be reduced insofar as the "new" state can better provide government services (Congleton, 1995), the "new" state is freed from structural redistribution to "poorer" ethnic groups in the context of the "old" state (Ferrero, 1995), the "new" state can avoid the breaking of economic cooperation with the "old" state (Young, 1994) or is successful in establishing profitable economic and political relationships with other groups (Meadwell, 1993; Dion, 1995; Hardin, 1995b; Salmon, 1995). Alternatively, the costs of secessionist behavior would be increased if the group in question is dependent on transfers from the central government of the "old" state (Findlay, 1995; Austin, 1996). To the extent that the "old" state is expected to retaliate effectively through the use of force this would raise considerably the expected costs of secessionist moves.

${ }^{10}$ The classic reference here is Olson (!965). For reference to the use of economic prizes to mobilize ethnic groups see Coleman (!995) and Ferrero (1995).

${ }^{11}$ The effect of economic downturns on ethnic expression in the market is more ambiguous. Insofar as the downturn is accompanied by an increase in unemployment this means that on the one hand employers with ethnic tastes face lower premiums when hiring fellow ethnic workers, while the cost faced by employees who refuse to work with other ethnicities increases (Leiman, 1993). In other words, ethnic expression becomes cheaper for employers and potentially more expensive for employees.

${ }^{12}$ See Bowles (1998) for a review of models and evidence concerned with the impact of markets on preferences.

${ }^{13}$ This points to the desirability of federalism in potentially divided multi-ethnic states. I discuss the merits and shortcomings of a geographically based federation versus a functionally based one in the context of one particular ethnic conflict in Kyriacou, 2000.

${ }^{14}$ See Reilly and Reynolds (1999) for an extended discussion of these and other electoral rules which could be suitable for divided societies. 